\title{
Household ecology, environments and technical processes among the Potiguara of Jaraguá village (Paraíba, Brazil)
}

\author{
Marianna de Queiroz Araújo' \\ ' Programa de Pós-Graduação em Antropologia, Universidade Federal da Paraíba, \\ João Pessoa/PB, Brasil
}

\begin{abstract}
This article focuses on the technical activities carried out by members of Potiguara households within the diverse environments that constitute the territory inhabited by these indigenous people. Such activities are the result of choices and strategies organized to meet the needs of these households (family groups of at least three generations), properly conforming a household ecology. The technical processes that result from this ecology are centred on individual and collective experiences in mangroves, floodplains and the patchy remnants of the Atlantic Forest, as well as in urban contexts, enabling the development of diversified skills and the acquisition of knowledge about techniques and materials. In this way, the Potiguara at present engage in fishing, agricultural, grazing and extractive activities, building on a local traditional knowledge that allows them to effectively associate materials of diverse origins, both those found locally and those of industrial provenance.
\end{abstract} Keywords: Potiguara; environments; household ecology; technical process. 


\section{Ecologia doméstica, ambientes e processos técnicos entre os Potiguara da aldeia Jaraguá ( Paraíba, Brasil)}

\section{Resumo}

O presente artigo focaliza as atividades técnicas desenvolvidas por membros de grupos domésticos potiguara no interior de ambientes diversificados, sendo estes partes constitutivas do território habitado por estes indígenas. Tais atividades são o resultado de escolhas e estratégias organizadas para atender às necessidades desses grupos domésticos (grupos familiares de pelo menos três gerações), conformando propriamente uma ecologia doméstica. Os processos técnicos que resultam dessa ecologia estão centrados nas experiências individuais e coletivas em manguezais, várzeas e resquícios de Mata Atlântica, bem como em contextos urbanos, permitindo o desenvolvimento de habilidades e a aquisição de saberes sobre técnicas e materiais bastante diversificados. Desta forma, hoje os Potiguara desenvolvem atividades pesqueiras, agrícolas, de pastoreio e extrativistas, a partir do aprimoramento de um conhecimento tradicional local que lhes permite associar de modo eficaz materiais de origens diversas, isto é, os encontráveis localmente e aqueles de procedência industrial.

Palavras-chave: Potiguara; ecologia doméstica; ambientes; processos técnicos. 


\title{
Household ecology, environments and technical processes among the Potiguara of Jaraguá village (Paraíba, Brazil)
}

\author{
Marianna de Queiroz Araújo
}

\section{Introduction}

This article studies the technical activities of members of Potiguara households ${ }^{1}$ inhabiting Jaraguá village in the Monte Mor Indigenous Land, situated in the municipality of Rio Tinto on the North Coast of the State of Paraiba, Brazil. The Indigenous Land is flanked by extensive mangroves, floodplains and patches of Atlantic Forest, lying some five kilometres from the city of the same name as the municipality. My aim is to understand these activities as constituting a household ecology2, defined by Wilk (1997) as the study of the relations of appropriation and management of resources. As the management of these resources are carried out in specific geographical spaces over which subjects intend to maintain a degree of control, a household ecology is concerned with the construction of areas of domain through what Barbosa da Silva and Mura (2018) have referred to as processes of domainization. It is through these processes that each human and nonhuman subject gives shape to domanial spaces, defining mobilities and trying to impose, through direct and indirect acts, their will and power over other subjects or collectivities - thereby, in turn, imposing limits of access to a given good, technique or knowledge.

The modes of accessing, interacting with and using the resources present in these spaces by the Potiguara enable the development of agricultural activities and the husbandry of small and large animals. They also fish in the mangroves, hunt and gather fruits and medicinal plants. In this sense, controlling a geographical space and seeking to order access to it is basic to household organization. The experiential trajectories of Potiguara subjects, as well as the household ecology that they develop, must thus be seen to be constitutive of the creation, conservation or transformation of the environments configured in these spaces.

Having or not having access to the resources of a territory differentially affects the day-to-day of households. Indeed, individuals are integral to the environments where they live and where they develop a household ecology that allows them to deal with their daily needs - whether as a guarantee during times of unforeseen necessities, or as a surplus that can be brought to the market in exchange for complementary resources. These activities are concatenated in the same time and space, through individual and collective strategies. These are directed to configuring itineraries that conform specific movements and temporalities.

Aiming to reveal these dynamics, my argument will be developed in three parts. First, I present theoretical considerations that shed light on the household ecology of Jaraguá village. Second, I describe the activities carried out by the member of the households through the knowledge that they transact, fruit of the experiences of using the resources available in the territory and socializing diverse knowledge, material and techniques,

\footnotetext{
Households are typically made up of individuals of three or four generations, making up a local group that, through specific forms of cooperation, connects a range of habitational units constituting aggregate households (Wilk 1984). In organizational terms, the basic social unit of the Potiguara are the households or "focal houses" (Vieira 2012).

2 The social organization of work defines the logic of cooperation and, eventually, the differentiation of tasks carried out by participants, breathing life into a household ecology (Wilk 1997).
} 
of local and industrial provenance. Finally, I investigate the temporal rhythms, as well as the knowledge and local conceptualizations that they give rise to, revealing movements that define cycles and alternations, delineating composite mobilities.

\section{Environments, Technical Processes and Household Ecology}

During my time with the households I was researching, I perceived that there are specific relations and understandings regarding the resources available in a territory, which include social, economic and political factors. This experience thus exceeds a symbolic dimension, embodying the know-how of the people involved. This relation between environmental elements is constructed out of a range of experiential resources which stem from the daily activities of the members of households.

The notion of the environment does not only include the ecological characteristics that distinguish one environment from another. Rather, this category, which is central to my argument, is to be understand in a more encompassing sense. I therefore use it as defined by Barbosa da Silva, in:

"[a] socioecological sense, comprising a specific material infrastructure (physical installations: constructions, paths, fencing, tress, pastures, streets, squares, etc), placing certain resources at the disposal of subjects and enabling the development of particular activities which, although characteristic, may not be exclusive. The environment is thus a physical space of relations, the constitutive unit of a territory" (Barbosa da Silva 2009: 88).

The environment is not only a physical space, including also a territorial component, which means a political dimension of control over the space where social groups live and relate to one another.

It follows that the relations that develop in day-to-day interactions are not based on a separation of what is "natural" from what is "artificial". Members of households build their relations at the territorial level, through the use of environments, where they establish itineraries out of choices and limitations that are imposed on them, allowing for the classification of materials, techniques and information that could not have been understood via a dichotomic approach. With a view toward overcoming dichotomies, Ingold and Kurttila (2000), in their studies of the Finnish Sami, observe that the acquisition of knowledge is inseparable from experiences and practices in the environment in which they live. Time is here a fundamental agent in "traditional knowledge as generated in the practices of locality"- LTK (Local Traditional Knowledge), a situated understanding that is dynamic, and which is formed and transformed by the experiences of people in interaction in this environment.

As peoples' experiences and learning is always related to the environment, it is useful to refer to F. Barth's reflections on the structure of social action through a differentiation of the notions of "event" and "act":

The former refers to the external aspect of behaviour, to objective date and measurable positivism. The latter, to the intentional and interpreted meaning of behaviour, to its sense for conscience persons with specific sets ofbeliefs and experiences. An event is an act by virtue of being intentional and interpretable. (...) The precipitate (in the chemical sense of the word) of interpretation of the acts in the person is his or her experience and, synthetically, in a more distanced plane, his or her knowledge and values, which, in turn, can retroact on future plans and goals, as well as on future interpretations of acts (Barth 2000: 173-174).

Following the author, we can understand how people pursue a certain culturally moulded logic, which is continually updated by the effective daily experiences of subjects in different social positions - and who, for this reason, maintain different explanations for the events, in accordance with their experiences.

In this vein, Ingold (2015) proposes that the notions of person, technique and environment are not stable and distinct categories, but categories concatenated in lived experiences. He thus starts from the notion of skill, indicating that culture is not constituted by symbols, but rather by actions and interactions in environments, 
through engagement in practical processes. He argues that people cannot be conceived independently from the skills they acquire and the technical processes that they promote.

Anthropological discussions of the relation between the human and technique include Leroi-Gourhan's pivotal elaboration of the analytical notions concerning technical processes: technical tendency - understanding the effects of human action on matter; technical environment - which propitiates changes at the technical level through the experience of a given place, bringing together creativity and borrowings from the technical knowledge of various regions; and technical fact - the elaboration of a specific technical trace, giving life to what is effectively apprehended by the researcher (Leroi-Gourhan 1984).

We can see here that the techno-economic activities carried out by the members of Potiguara households are made possible by the environmental characteristics of a floodplain area and a vast mangrove, with occasional patchy remnants of Atlantic forest, and that they are put into effect from knowledges, tools and practice which, articulated with each other, make up specific technical sets (Leroi-Gourhan ibid.). These make possible the production of diverse objects and activities within a circumscribed space. Thus, as they carry out their activities, the members of the groups interact intensely within environments, which also include urban clusters, displaying a mobility that ensures access to different technical and material knowledge, which are then incorporated into the social organization of work through the distribution of competences. The local and experiential dimensions emerge as significantly relevant for defining territorial dynamics and technical processes, to which we may here add the pre-eminence of domestic strategies and technical transformations. In the next section, I will explore these connections and their empirical and technical implications.

\section{Domestic Strategies and Technical Transformations}

The Potiguara Indigenous people have long occupied territorial spaces in the northern coast of the state of Paraiba, encased between the mouth of the Camaratuba River and the Mamanguape River, in the northern limits of the Mataraca municipality and the southern stretch of Rio Tinto. They are distributed throughout 32 villages, belonging to three contiguous Indigenous Lands ${ }^{3}$, located in the municipalities of Baía da Traição, Marcação and Rio Tinto.

I will not be able to dwell on the history of the Potiguara in this area in the $18^{\text {th }}$ and $19^{\text {th }}$ centuries, but it is important to note that historical sources register that they were settled in two villages, assisted by missionaries of the Carmo da Reforma de São Miguel da Baía da Tração, situated on the coast of Paraiba, and by those of the Preguiça, some $24 \mathrm{~km}$ inland (see Palitot 2005).

In the second half of the $18^{\text {th }}$ Century, the villages of São Miguel and Baía da Traição was modified by Pombaline laws which expelled the missionary orders and changed the status of the villages, which became "Indian Hamlets". After the Law of Lands was passed in 1850, the authorities' neglect of the precarious condition of the Indigenous people allowed for the constant usurpation and sale of Indigenous lands (Palitot ibid.). In the first decades of the $2 \mathrm{o}^{\text {th }}$ Century, two agencies began to operate in the region: the Indian Protection Service (Serviço de Proteção aos Índios - SPI), in the Baía da Traição, which established a tutelary regime of control over the Indigenous territory, and the Rio Tinto Textile Company (Companhia de Tecidos do Rio Tinto), belonging to the landowning Lundgren family. On the one hand, the official agency for Indigenous affairs was based on the idea of incorporating Indigenous people into national society. On the other, pressure on traditional Potiguara territories intensified through the activities of the Lundgren family.

\footnotetext{
3 The Potiguara Indigenous Land (TI Potuguara), with 8,109 inhabitants and 21,238 hectares; the TI Jacaré de São Domingos, with 449 inhabitants and 5,032 hecatres; and the TI Potiguara de Monte Mór, with 4,447 people and 7,467n hectares (see Cardoso et al 2012: 15).
} 
These agents and agencies promoted what Oliveira (2004) defines as a process of territorialization. ${ }^{4}$ In the 1980 , with the advent of the National Alcohol Programme (Proálcool), many of the lands of the Company were sold to sugar mills. The mills invested in the areas formerly explored by the Company, buying and/or letting them, which brought further hardships to the social reproduction of the inhabitants, with increasing limits on access to resources.

Deforestation for sugar cane plantation transformed the physical scenery of social and technical relations. The expropriation of lands and the expansion of sugar cane cultivation led to widespread discontent, requiring the Potiguara to seek the demarcation of their lands as early as the 1980s. ${ }^{5}$ Most of the so-called retomadas ("re-takings") involved substituting sugar cane plantations for manioc gardens. The re-takers would plant gardens which were later destroyed on the orders of the mil-owners. Strategies for resisting domination, including initiatives for recovering and defending territory, ensured that productive activities were carried out, and were marked by a change in the relations of power that had underlined spatial relations. Through the acts of re-taking, Potiguara lands gradually resumed the horticultural and husbandry activities that had previously been banned by the Company and the mill-owners. However, these changes did not alter the situation imposed by the State.

The act of territorializing, here understood as a form of domaining, that is, as the production of domains (Barbosa da Silva; Mura 2018), is not a one-way process: on the contrary, Indigenous subjects respond, participating in the effects of this domaining through the household ecology that they put into practice.

According to Wilk and Netting (1984), the household is often a privileged unit of description and analysis for understanding relations between production and consumption. In my view, however, production and consumption are not only related to material goods, but also include the production and transmission of knowledge, the education of the children of the household, and a range of other activities. In this study, I will reveal some of the activities of individuals belonging to households in the village of Jaraguá, in specific environments, among them the patio, the mangroves, the garden and the city. It is thus necessary to understand how these groups are organized and, consequently, how they relate to the other elements and beings present in this environment, as well as trying to understand how domestic strategies and technical transformations are generated form these relations.

It is important not to lose sight of the fact that the occupation and use of space is always a dynamic process, involving various agents. Before the establishment of a dynamic proper to Capitalist development, with the exploitation of a workforce and the extraction of resources from their territories, the Potiguara could engage in their activities in an environment (Barbosa da Silva 2009) that fulfilled all of their needs. In time, biodiversity in the territorial spaces of the households was drastically reduced, resulting in a specific ecological configuration. The "Company" and the mills played a major part in this, through the extraction of timber form the native Atlantic forest and sugar cane plantations (Barbosa da Silva et al. 2017).

Intense deforestation did not simply result in the drastic reduction of animal and vegetal populations (both in individual numbers and in variety); the phenomenon also caused significant modifications in hydrography. With the mills, sugarcane stretched into the productive space of the Potiguara, ravaging existing areas of vegetation and restricting agricultural and fishing activities. The best land (the chãas) was used for sugarcane plantation, leaving hillside outcrops for food cultivation. In this new context, the members of Potiguara households nonetheless continued to carry out their activities through their traditional knowledge,

\footnotetext{
4 Oliveira understands territorialization as a process of social reorganization that implies: (i) the creation of a new sociocultural unit through the establishment of a differentiating ethnic identity; (ii) the constitution of specialized political mechanisms; (iii) the redefinition of social control over natural resources; (iv) the re-elaboration of culture and of relations with the past (Oliveira 2004: 22). He defines "territorialization" as "an intervention of the political sphere that associates (in prescriptive and unquestionable terms) a well-defined territory to a set of individuals and social groups” (ibid: 23).

I am unable here to explore how the households came to be articulated as political communities (Weber 1999) in order to make the "re-takimgs" possible. A type of sand soil suitable for cultivation.
} 
stemming from experiences of using the resources available in their territory, developing adaptive strategies in socio-ecological-territorial contexts that have been defined historically (Mura 2011). The lack of productive space for horticulture has led some households to adapt reduced spaces, such as backyards ${ }^{7}$, as well as floodprone deforested mangrove lands, which are filled with earth. Likewise, industrialized good, articulated with those of vegetal origin, started to play an important role in the construction and acquisition of artefacts (Araújo 2015, 2017).

What therefore matters to subjects when they make technical choices is that they be able to count on possibilities, regardless of whether the materials are "natural" or "artificial". The territorial aspect is here relevant, for it allows us to understand subjects' levels of spatial mobility and the reach of desired objects. Domaining areas are thereby defined "to enable a better organization of access to these flows and control over them, as well as to sediment knowledge and skill acquired through experiential trajectories to which the subjects gave internal life, starting from and moving beyond these spaces" (Barbosa da Silva; Mura 2018:4).

Through the description of certain types of practice it is possible to distinguish and understand the technical knowledge manifested by members of the households, through skills tuned to actions and interactions in the environment and engagement in experiential processes (Ingold 2015). The range of tasks that Potiguara households can engage in through use of both "natural" and "artificial" materials is indeed wide. For instance, the mangrove wood known regionally as sapateiro (Rhizophora mangle) is used not only for covering houses and building fences, it also extends the durability of fishing nets made from a synthetic material known as 'silk'. First, wood needs to be gathered in the mangroves. It then undergoes a chemical process where it is chipped and kept in water for a week, after which the nets are put into the tank to absorb the paint and thicken the fibres of the "silk". This process relies on a local knowledge that associates the chemical properties of the wood to those of the net's fibres.

Photo: Silvinha with his nets for capturing fish, crustaceans, etc., made from "silk" threads acquired from the local commerce

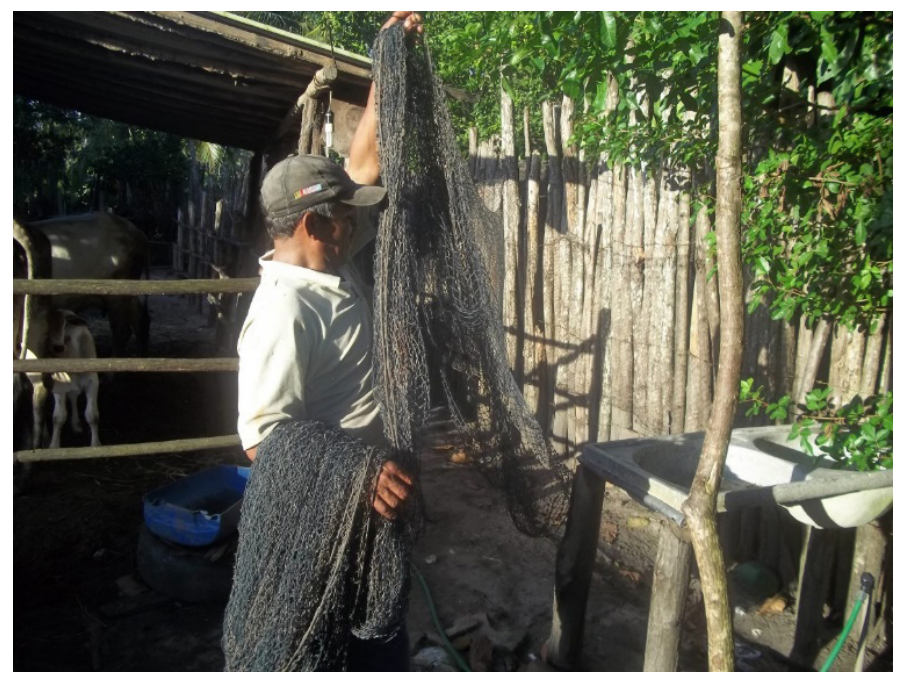

Photo by the author, 2014.

\footnotetext{
7 Yards are situated outside the habitations. They are characterized as a social and symbolic space of many uses which manifest and make possible the organization of groups, being a space constructed according to member's needs. This environment of domestic spatiality is frequently used, sometimes serving as a tool deposit, animal pen, and a place for culinary activities and planting.
} 
Tank with the mangue sapateiro paint, used to extend the durability of the fishing nets made from "silk" fibres

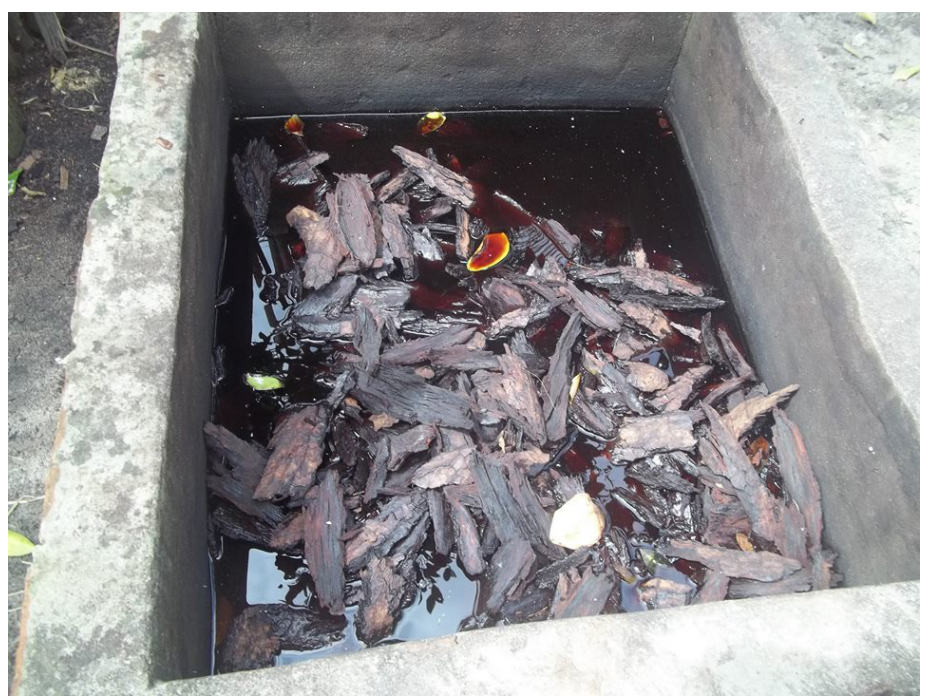

Photo by the author, 2014 .

The images above refer to some of the activities of Silvinha, who spends most of his time fishing with nets. He is married to Sônia and two of his sons (Cristiano and Rafael) sometimes help him in this activity. Leonardo, the middle child, is working in the city of Piracicaba, in the state of São Paulo, and a part of his wages helps with the family's stipend. Silvinha goes to the mangroves almost every day, and most of the fish he catches is sold by his wife in the village or, when the catch is bigger, in the Rio Tinto market on Saturdays.

The broom is another sort of local knowledge which effectively conjugates diverse materials. It is made from the leaf stalks of the coconut tree, which are grouped in a fan shape. Industrialized products such as string and rubber are used for finishing. To fix the handle, empty plastic deodorant cannisters are used, which are acquired in local commerce. These materials are easily accessible, and are not expensive.

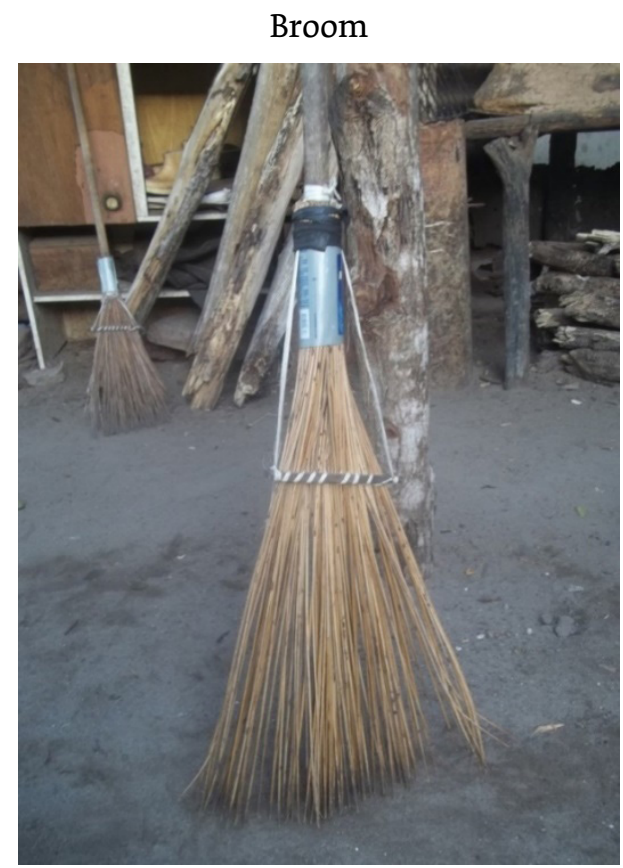

Photo by the author, 2014 . 
As well as those implements mentioned above, traps and fishing instruments can be made from cans, plastic, PET bottles, PVC, rubber, and other materials. These are essential elements for understanding the composition of the material baggage of households and the technical knowledge related to them.

The "rat trap" (ratoeira) is used to capture the blue land crab (Cardisoma guanhumi). It is generally produced with discarded materials, such as PET bottles, PVC tubing, rubber and scraps of wood. On average, people place ten to twenty "rat traps" per day near crab burrows. Bait, which can be pieces of pineapple, onion, or anything with a strong odour, is placed inside the trap. When a crab, attracted by the bait, goes into the rat trap, the trigger is set off and traps it. This process can take hours, so rat traps are usually left overnight. The Potiguara use old tractor tires cemented to the ground to breed and fatten crabs.

"Rat trap"

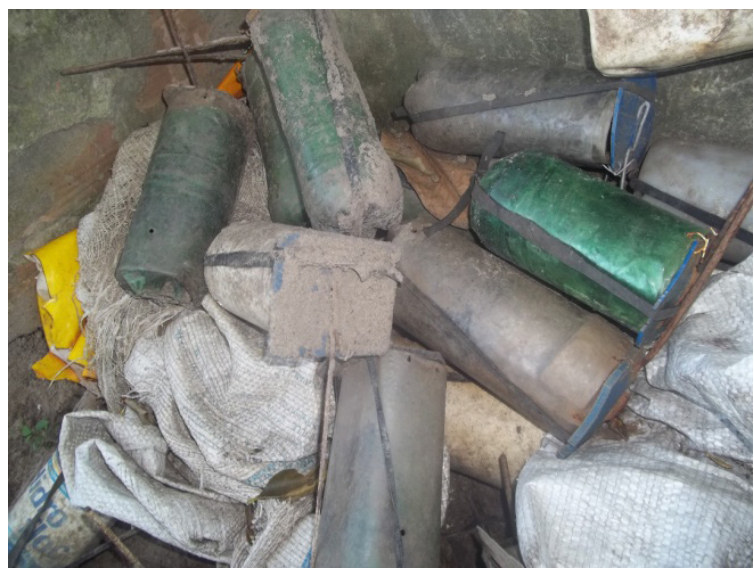

Blue land crab breeder made from tractor tire

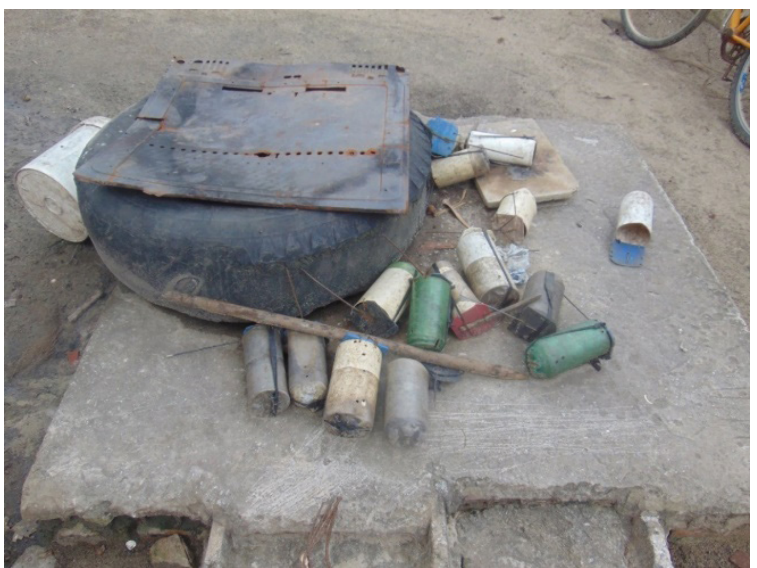

Inside the blue land crab breeder

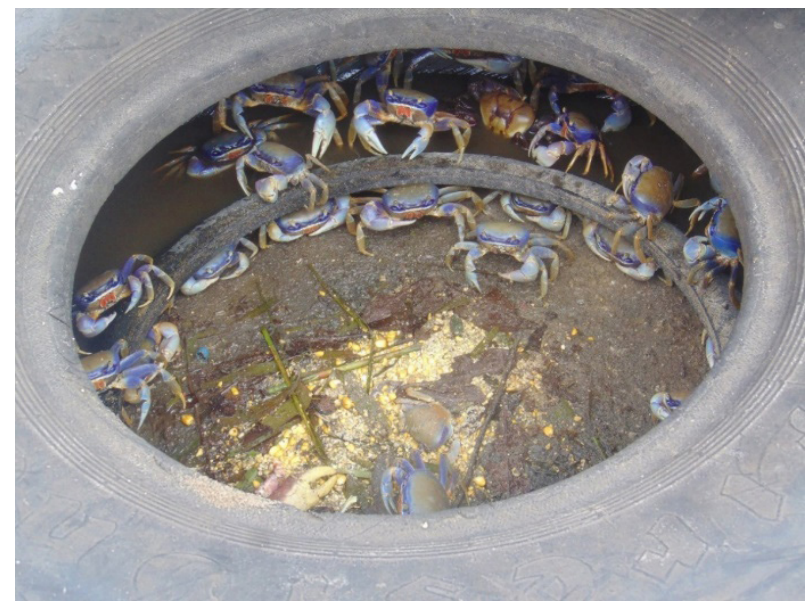

Photos by the author, 2017.

The covos are portable fishing traps with one or more openings for fish to go in, and they are very useful for capturing shrimp and fat sleeper fish (Dormitatur maculatus). Covos can be cylindrical, semi-cylindrical or rectangular. The mouth through which the fish enter is funnel-shaped. They may be made from bamboo and tied with "fire vine" (see photo below), but more recently they have been made with plastic fibres, wire, screens, among other materials. In the top or lateral side there is an opening, from which captured animals are retrieved. 
To store fish and crustaceans, a sort of receptacle basket with a spherical rim and a plane base known regionally as a samburá is used. It is an arched weave, made of "cinnamon vine", "stick vine" or "blood vine", with a simple selvage as a finish. It also has a round lid. Today, flexible or semi-rigid vegetal elements are frequently replaced or complemented by other materials which can be easily accessed, and which prolong the durability of objects. Vines have of late been replaced by pieces of PVC tubing, joined by nylon strings, with a sapateiro wood handle obtained from the mangroves (see photos below).

\section{Covo made of bamboo and "fire vine"}

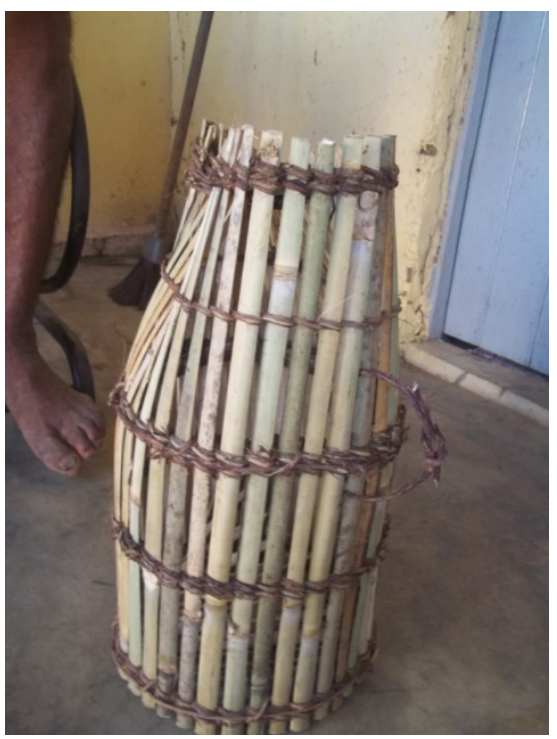

Photo by the author, 2014 .

Samburá made with PVC tubing, nylon string, and sapateiro wood from the mangroves
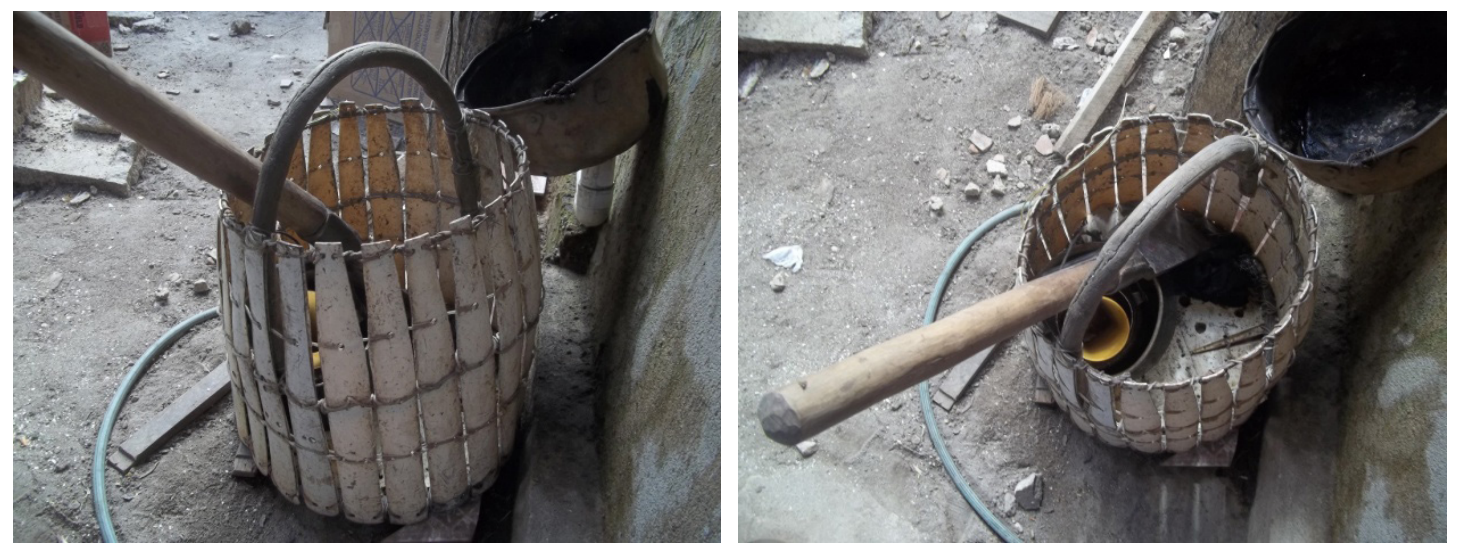

Photos by the author, 2016.

The variety of knowledge, techniques and activities developed by the Potiguara of Jaraguá village is quite extensive. The objects and instruments that have been described do not exhaust them. My aim has simply been to provide a few examples so that the reader might have an idea of the preponderance of these goods in Indigenous domestic life. 
These objects are characterized by the association of material of diverse origins. The aluminium cylinder of a deodorant cannister, for instance, becomes a material that can fix the handle of a broom to its tip (see photo). The $90-100^{\circ}$ angle formed by the branches of magrove sapateiro, joined by their physical properties, ensure that these are privileged materials to construct the canbo caves (see photos). The technical choices of the Potiguara of Jaraguá thus take into account not only the physical and/or chemical properties of the materials, but also the forms that they acquired in previous processes, regardless of whether they are of industrial or local origin.

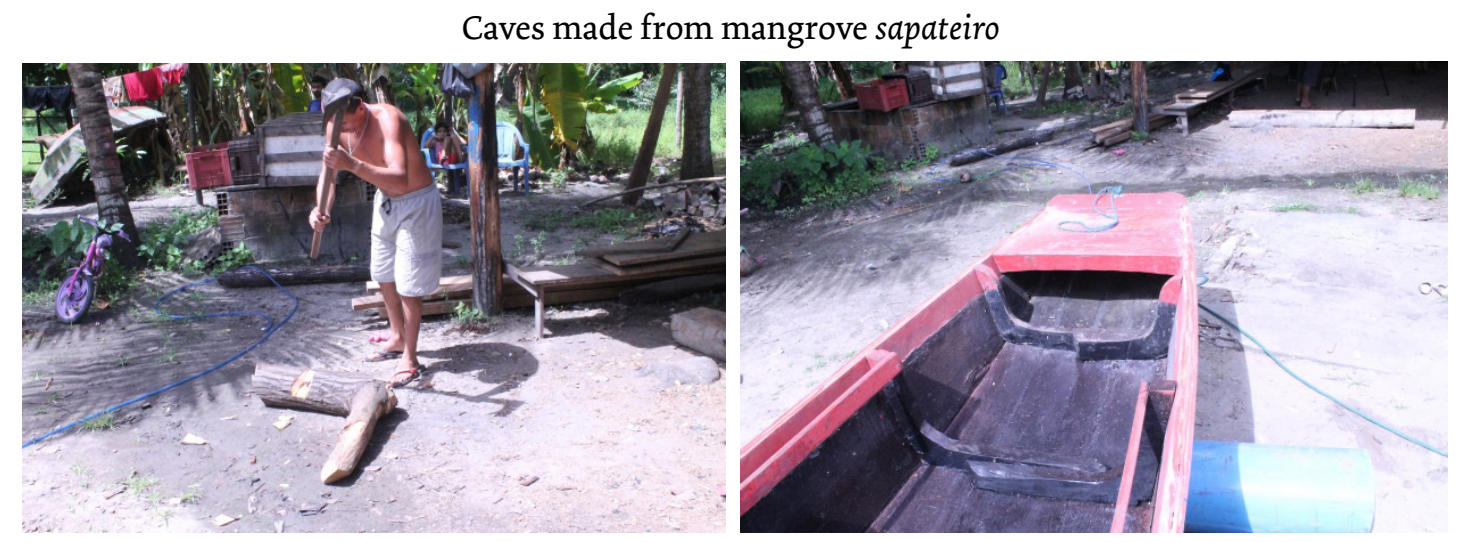

Photo by Darllan Neves da Rocha, 2018.

According to Lemonnier (1993), technical choice is the analysis of the process of selecting a technical resource, locally elaborated or acquired elsewhere, by focusing on its action on matter. During these processes of selection, new technical objects are included as technical processes in a wide sense. In my approach, the examples described above were exposed as technical choices that reverberate changes in the ways the Potiguara deal with materials and develop technical competences, transforming them toward a certain goal. Technical choices thus express the experiences of individuals in the environments where they dwell. These experiences depend on a vast territorial situation, which requires a consideration of the availability of materials that an environment offers, as well as their accessibility. (Mura 200o). According to Mura:

We must consider the conditions that are given for the formation of conjunctures that enable an availability/accessibility dialectic and the decision of those interested in the technological process. These decisions depend greatly on the values that social actors attribute to dwelling, to the material world and to time. (...) The availability of materials and their accessibility in the territory influence both the conditions of the same territory and the possibilities of decision-making of the social actor, who can participate in this process at different levels. Hence the interactions of the scenery - as ends, plans, and expectations - with the availability/accessibility dyad, will determine what we define as a repertoire of possibilities. (Mura, op.cit.: 66)

The acquisition of technical knowledge hence depends on the presence of a favourable technical environment, wherein elements are determined by human and nonhuman acts, with the requisite combination of availability and accessibility. Some form of jurisdiction is therefore necessary to access the territory, which brings us into a geographical and political level. An example of outside influence on the territorial management of the Potiguara is the Instituto Brasileiro do Meio Ambiente e dos Recursos Naturais Renováveis (Ibama, Brazilian Institute of the Environment and Renewable Natural Resources). The village of Jaraguá sits within an Área de Proteção Ambiental (APA, Environmental Protection Area). Employees of the Ibama therefore place certain restrictions, such as, for instance, limiting the wood gathered from mangroves. This practice was prohibited for a time, though it is very important for the domestic economy of the Indigenous people. Gathered wood and leaves are used for fencing, covering houses, constructing work tools, fire, and so forth. As to the interventions of the environmental agency, Silvinha reported the following: 
They want to stop us from getting some wood there, but that wood on the floor it's no use anymore, up there it's more important, if you deforest here, there the water will dry up, that's it, and the tide will hit us. They have to look at this there. Look over there; it's all burnt. They don't see that the main thing are the sources of water, they only see the mangrove. Because sometimes the wood is overturned and we make charcoal. I don't agree when they remove saplings, I live in here, I have to preserve that there. The mangrove alone, it finds a way, but just because there are people it doesn't mean it's going to die right? No, it doesn't die (Silvinha. Interview in December 2016).

Fishermen periodically clean fishing areas, removing tree stubs and mangrove porpopoté roots, so that they remain free for boats to reach the main channel of the rivers, or to leave the mangrove, thereby avoiding landfill areas. According to Silvinha:

It's God's work, but without man's hands to help, it will also destroy itself. There is a place that we fixed in the mangrove; the wood was all overturned. We cut it: it was beautiful! Today the wood is big, we have to go again, because the wood is already inside the mangrove; it starts flowing down and it dams the river, the garbage (leaves, branches) goes down; then it fills it up (Silvinha. Interview in December 2016).

From the narratives, it is possible to see that there are conflicts, particularly in what concerns the extraction of wood from the mangrove. However, the inspection agency imposes restrictions on the inhabitants of the area, and the latter question and often disrespect these rules, because the space has been occupied by Indigenous people since long before the APA was created, and Indigenous usages and customs have been reproduced in this space for centuries. There is here a political dimension of limited accessibility to the territory and its resources, which conditions the development of the household ecology. This configuration results from practices of territorial and ecological control and domination. Faced with limitations on their activities, the Potiguara react by establishing strategies and participating in political movements to recover the administration and use of the territories that they have traditionally occupied, as is made clear in the words of Anibal, the village headman':

When they say "it's this" we say, "no, it's this way". When they forbid, we hold a meeting and say "our custom is this one here, you can't now forbid us from using our nature". They, who arrived here, wanted to forbid Indians from gathering dry wood in the mangrove. This dry wood is already dead, it's no use, you have to remove it. They said we couldn't do it, and we said "yes we can". Now, cutting down the mangrove to plant - no. So when they decided to remove stakes to make fencing, we forbade them; let's call IBAMA to arrest them. Because with stakes, the trunks are bigger. Then they take, let's say, they take one thousand stakes, that's too much. So anyone who wants stakes is going to have to buy them, because they ain't getting them from the mangroves. Now, to build a house, we allow it, because we see that there is a need; then you've just got to (Anibal. Interview in January 2016).

Faced with certain situations, the inspection agency holds the inhabitants of the area responsible for what they see as damage to the environment, which further restricts their subsistence options. A dispute thus arises between distinct modalities of management or access to and use of resources, and by the socially unequal display of the environmental damages and risks caused by industrial endeavours during the historical process. It is precisely against the conditions imposed by dominant policies that the Potiguara seek to impose their own power, to access and control the resources present in their territory - through the household ecology, where they build domanial spaces and define mobilities, as we will see in the following section.

8 Aníbal is married to Cássia. Relations within their household are configured by the couple and their three children. Grandparents, parents-in-laws and brothers-in-law which live nearby cooperate with each other with certain tasks, such as fishing, hunting, gathering wood and planting gardens. 


\section{Temporalities and movements}

From what we have seen thus far, it can be said that activities carried out in the environments enable the refinement of different technical knowledge that results from the practical experiences of members of households. These experiences are directed at configuring inclusive and exclusive spaces in which domain is affirmed over a certain geographical space (Mura e Barbosa da Silva 2018).

In the present case, the habitational unit is the space of exclusive use by members of households. This exclusivity allows for control over the areas aggregated to the house. In contrast, the mangroves, the floodplains and the forest are inclusive spaces, the resources of which are jointly accessed and used by the members of different households.

The temporalities and movements that construct these domanial spaces, much like the criteria that determine accessibility to them, configure an ecology of Potiguara households that creates the conditions for establishing itineraries, contemplating mobilities, fostering interaction in the environments, with the resources present therein. The success of the activities is directly related to specific temporalities. As there is a time for fishing and a time for planting, these understandings are formulated in experience, informing the process of accumulating knowledge of climate, fauna, flora tidal regimes, which are part of the dynamic of the groups within the territory. The seasons, for instance, are characterized as follows: the first rains occur when it is still Summer, in the months of January and February; between the winter months of March and August the rains are intense. Summer starts between September and October; November and December, the months of Summer proper, are considered to be the hottest months of the year. The best time for gardening corresponds to what Evans-Pritchard (2005) calls ecological time, a time defined by the cycles of the environment to which the social groups adapt and which they mould through regular activities. For the Potiguara, the dimension of time is established by work in the gardens, which is divided into two periods: a time of waiting and a time of harvesting. The first rains of January signal the start of planting, when the members of households gather with the aim of cultivating gardens, which are "cleaned" so that seeds can be planted and germinate.

People cultivate in the Sandy soils called arisco during the rains, and in the dry season the make their gardens in the waterlogged pau soils. Soil is an indispensable element in agriculture. It is a renewable mineral resource that is essential for plants which develop from within it, taking nutrients and water for germination, growth and later production.

Yams, manioc and beans are cultivated in January. The time of planting extends into May, in which beans are planted. Manioc is usually planted by itself, or interspersed with beans and maize, with planting beginning at the start of the rainy season. The "garden" (sweet manioc) can be planted throughout the year. As the Potiguara often say: "Everything that's planted will depend on the 'waterness' (aguação)", that is, on the amount and availability of water. The wait for different food varietals thus depends on distinct temporalities. Products cultivated during January are harvested in August, those planted in March are harvested in June, and those planted in May are harvested in August. The dynamics of planting, cultivating and harvesting is part of a constant cycle for members of the households.

Alongside the climate regime, those Potiguara who fish - which are most of them - also guide themselves by the tidal cycles. For any type of fishing, one needs to know the movement of the tides; the perception that fishermen have of the cyclical regularities of tides is this crucial for success in fishing.

Tidal cycles, however, are more important ecological factors, since they influence the way of life of animals and how fishing techniques are defined. They are directly affected by lunar cycles; during a waxing moon the tide "launches" itself, that is, it grows until reaching a "full tide". 
When the moon is waning, the tide reverts to "breaking tide", until it reached a "dead tide". Mr Zé Boto", an older fisherman in the region, explained to me that the tide "works" according to the moon, noting that there is a "last quarter tide" and a "full moon tide":

There, the last quarter will be a small tide, it doesn't put out much water, because it's the last quarter, right? Now, when it's the other, the full moon, it heaps from day to night, it's dry today, when it's tomorrow it goes away... Because the tide is big (Mr Zé Boto. Interviewed in July 2013).

The tidal phases are thus observed during the day, particularly by the fishermen, consisting of the following denominations: "full", when it reaches its maximum point; "waning", when it is decreasing; "empty", when it is at its driest; and "waxing", when it is filling up. The movement of the tides corresponds to two processes. The first is longer, and refers to weekly cyclical alternations, while the second refers to alternations that occur over one day and one night. During the "big tide" the volume of water rises and decreases in all of its capacity. During a "dead tide", there is little variation, the tide neither waxes nor wanes, never coming to fully flood the mangroves.

Individuals notice the variation in the tides along a monthly and daily cycle, and they understand that this variation occurs in relation to the strength of the moon. The moons are called new, waxing, full and waning. These phases of the moon are associated with monthly tidal cycles, called "big tide" when the moon is new or full; and "dead tide "when the moon is waxing or waning.

The mangrove is an economically profitable environment for the Potiguara. To live off the mangrove/ tide is to establish daily behaviours and routines interlinked with this environment. The mangrove is a "way of life", it is the environment in which the main local productive activities are carried out. It is where fish, crustaceans and molluscs are obtained, and a space upon which many of the inhabitants of the area depend for a living. Fishermen and women have very keen knowledge of the mangrove, and are hence able to locate aquatic animals and develop efficient techniques for capturing them. The carry out their activities individually or in partnerships, usually among close kinspeople, such as a father, a son or brother. Produce is divided into equal portions. Part of the fish is consumed or given to kinspeople and neighbours with whom one is on friendly terms, and part is sold in the village or in the local market when the catch is bigger.

Even those (male) individuals who work harvesting sugar cane for the mills stop work after the milling period and return to the mangrove. Mill works is seasonal, usually beginning in July and extending until late March, so that people have from April to June free to fish and gather crustaceans, or else to engage in informal waged work. Many women also gather oysters in the mangroves.

However, it must be stressed that the activities carried out in this environment are not exclusively motivated by financial gains. As I have mentioned, animals obtained from fishing and gathering are not only sold out; they can also be given to neighbours, friends and kinspeople, establishing and consolidating networks of reciprocity. Fishing is thus more a way of life characterized by rich and complex relations between people and the aquatic environment. Processes of production and transaction of knowledge and the spatial organization of technical activities occur within this meshwork.

The main plant species found in the mangroves are the "tame" mangrove tree (Laguncularia racemosa), which is mainly used to make fire. This mangrove tree has a darker trunk, and smaller roots. The "sapateiro mangrove" (Rhizophora mangle) has higher roots and, because of its resilience, it is mainly used to cover habitations. Rafters, clapboards and staffs are also made from "sapateiro" mangrove.

\footnotetext{
9 Mr Zé Boto was born in Jaraguá and married Fátima, with whom he had eight children. Three of them live in the village, while the other five have moved to the Southeast of Brazil. Mrs. Fátima and Mr Zé Boto are the supporting axis of the household, not least because they raise six grandchildren while their parents are working in the Southeast. Cooperation among the members also turns to food preparation, animal and garden care. Older grandchildren help their grandparents cutting grass for goats, collecting wood for coal, and take animals to pasture and back to the corral.
} 
Wood is also used to make henhouses, corrals and goat pens. "Canoé" mangroves (Avicennia germinans) are large trees. Their deep roots rarely give, and most are situated in the areas of the swamp in which mud is mixed with sand (Araújo, 2015: 35).
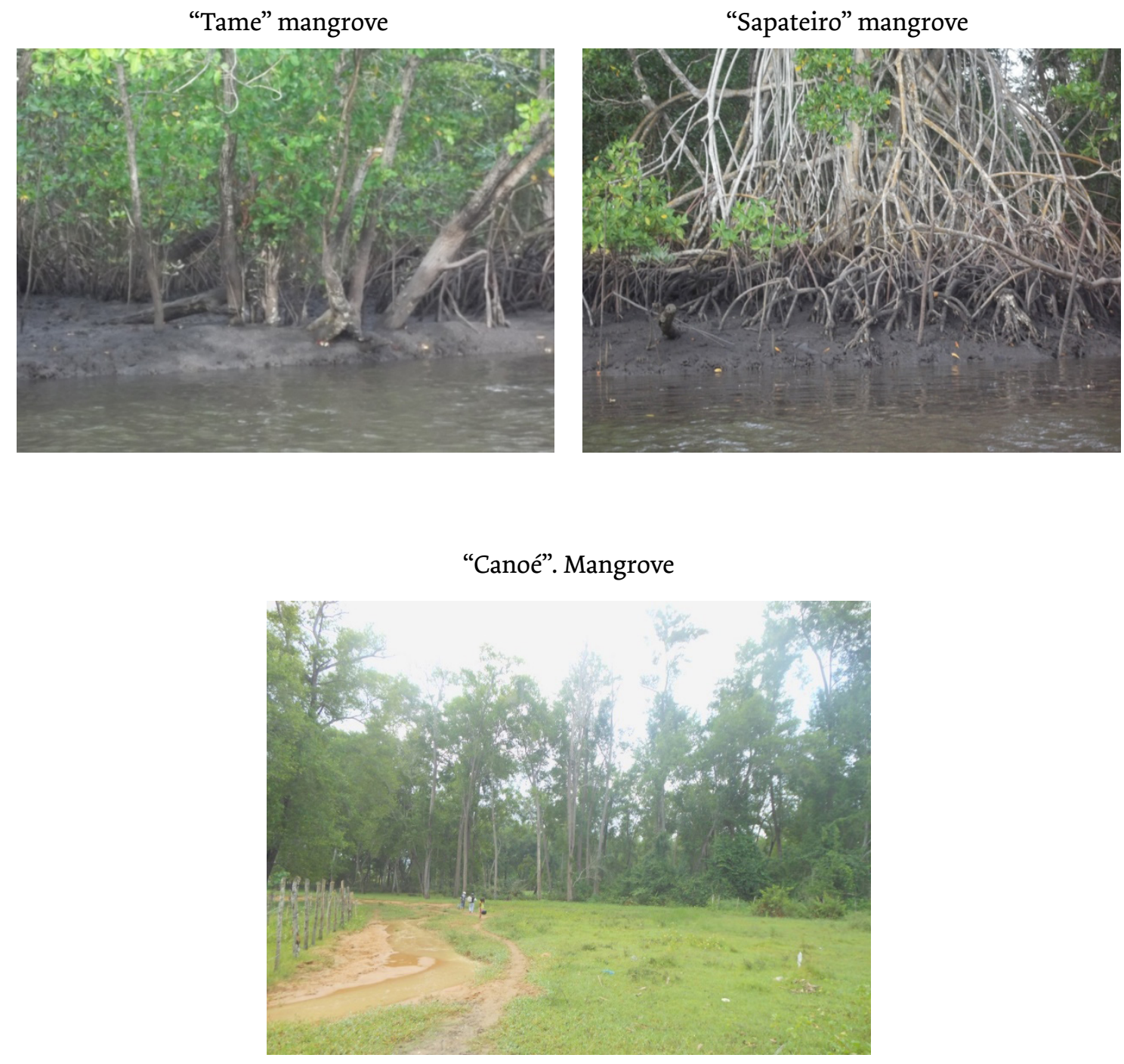

Photos by the author, 2013.

The mangrove is made up of "places" or "sectors", designated according to their physical characteristics. There is the "soft manioc mangrove", "the cut foot mangrove", the "fallen hill mangrove", among others, which fishermen name to facilitate work and orientation. In these places, fishermen create exclusive spaces within shared areas, naming them and often delimiting them through spatial markers, constituted by strips of tape and plastic bags tied to sticks plunged into the mud of the swamp. These markers indicate to other fisherman that the area is temporarily occupied, and that they should search elsewhere. There is this an alternation of these areas which fishermen call "sectors".

According to Silvinha, it is not advised for one to fish twice in the same "sector":

Let's suppose that we removed a net from this sector, only one month from now do we put it again in that sector, because of the pisunhando (footstep in the mud) right? Which raises the bad smell, so iffifteen days later you go back there you get the pisunhando, and the fish broods right? Only one month later then, because of the pisunhando which the fish knows, each fist of net I give four spins on it, we step a lot on the mud, that sour smell rises up (Silvinha, interviewd in December 2016). 
In Silvinha's report, the fish communicate; they "brood" with the pisunhado of other beings and move away. Fish thus act, as they interact with fishermen. This perception is constituted from the fact that the individual is in an environment in which he relates to other beings. To paraphrase Ingold (2012), the relations established are founded on the adaptation of cognitive skills to the environment; that is, the world is only lived with and around it, which is linked to the capacities to act, think and establish relations with each other and the world of which they are a part. This dynamic conforms to the knowledge based on the experiences of Silvinha, for example, and the recognition that, like men, marine beings are acting subjects.

Another fact, tied to same sort of knowledge which corresponds to the experiences of Silvinha in the mangrove, is his skill at seeing in the dark:

When I began to fish, I couldn't look to the side because everything was dark, when we walk in the dark for a long time our eyes adapt. Today I can see things that I couldn't before. (Silvinha, interviewd in December 2016).

This skill was acquired with time, during interactions in the environment, and can be described as a dynamic synergy between the organism and the environment, as proposed by Ingold. According to Ingold (2002), human beings - during their interactions with the world - are not confined to their bodies, but entwined in an environment-organism system. Referring specifically to fishing, Cordell (1974) claims that it is an activity that functions as a man-environment system. In this connection, the adaptive process during fishing furnishes an intricate knowledge for finding fish.

As far as locating fish is concerned, there is a tendency on the part of economists to discount important intuitive aspects of environmental decision-making; the assumption is that fish must be sought blindly (Christy and Scott I965: 88). In general, there is little appreciation of how, and to what extent, fishermen make use of environmental clues to predict the behavior and movement of different species. It would be quite misleading to assume that canoe fishermen face a kind of "separate" reality when they are dealing with their fishing environment. On the contrary, fishermen do consistently know where the fish are, and it is this widely shared knowledge, not simply the fact that they are using a common property resource (Cordell 1974: p.379).

Mangroves also include the camboas, which are paths that enable the passage of canoes and also serve as fishing areas. Fishermen tend to say that they "work a camboa". Fishing is also possible in the so-called croas, areas of the swamp with a concentration of sand.

There is a temporal change in views of the mangrove. Older residents say that the mangrove used to be very different from what it is today, with an abundance of resources. They attribute the loss of resources to deforestation and to landfilling of the rivers because of the sugar cane monoculture. There was more fish in the past. However, the recognize that today they can make a greater profit. The mangrove used to be closer to their villages, which made the work of fishermen easier. Today the mangroves are far away:

The mangrove is ending because of deforestation (...) The sand has come down, damned the river, that "hole of the priest" that they talk about, all that sand comes down to the mangroves during the rains (...) This part here on top, it was all forest, the mill cut it down to plant sugar cane, and the sand then got soft, since that's up high and we're here down low, of course it's all going to come this way! Then they deforested it, and so here where we used to get the black shrimp, it's all damned, there is no more (Silvinha. Interviewed in December 2016).

Among the main fishing techniques is the "taking net" (also known as the "waiting net"). It is directly tied to the rhythm of the tides, since it is set when the tide is waning. When the tide is waxing, the net is raised, creating a barrier in the camboa. It is "unfished" (gathered) when the tide wanes again. Sticks are spread through

10 A long and deep ditch in Jaraguá, caused by erosion. 
the bed in the perimeter where the nets will be attached with the gaitas ${ }^{11}$. Silvinha, for example, sets up 300 meters of nets in sequence, attached one to the other, surrounding all of the camboa. The fish enter the camboa as the tide dries up; when the tide rises, the net is raised and the fish are gathered:

In the breaking Sunday, from mid-day to twelve o'clock we're arriving with fish, then Saturday at 3 o'clock we put it, then we go back home and then when it's 10 I go down to raise it, unfish on Sunday morning. We don't like to throw it, because we take two days and the breaking, with three days you've got two tides, because you work today and gather at night, and next day you start again. (Silvinha. Interviewed in March 2017).

To paraphrase Cordell (1974), we may say that fishermen take note of miniscule details, related to how the tides condition the choice of technique, but also to an understanding of how a trip to the mangrove is to be planned. The position of the moon, along with an observation of its phases, indicate whether fishing is feasible. Fishermen must furthermore know which specific sequence of tidal changes will occur during the part of the day that they have set aside for fishing. It is this aspect of knowledge of the tides that is most useful for ensuring large catches.

The most common fish in the mangrove are: Brazilian mullets (Mugil brasiliensis), mojarras (Eucinostomus gula), the common snook (Centropomus undecimalis), catfishes (Siluriformes), goldfish (Carassius auratus) and the flathead grey mullet (Mugil cephalus), classified as follows:

Classification of fish according to water zones

\begin{tabular}{|l|l|}
\hline Floating Fish & Deep Fish \\
\hline Brazilian Mullet & Amoré \\
\hline Flathead grey mullet & Mero \\
\hline Goldfish & Catfish \\
\hline & Common snook \\
\hline & Mojarra \\
\hline
\end{tabular}

Table elaborated by the author.

There is furthermore a fishing technique with drag nets, in which the fisherman throws the net in a perimeter that he knows to contain fish, so that the mesh opens up as much as possible before hitting the water. He then pulls it to capture the fish that became caught in it.

Oyster (Crassostrea rhizophorae) gathering is also important for the diet and income of the Potiguara. This mollusc gets caught in the roots of the mangrove, and the fisherman dives to remove them with a machete. It is also possible to gather oysters when the tide dries up, or by cultivation, a technique involving "cages" (woven baskets) attached to trunks and fixed to bed of the mangrove swamp.

The swamp ghost crab (Ucides cordatus) (uçá or "salt", as it is usually called), as well as the blue land crab (Cardisoma guanhumi) are captured in the mangroves all year round. However, during the "walking" season (January-March), the reproductive period in which male and female crabs leave their burrows and wander through the swamp, they become more frequent (particularly the swamp ghost crab).

The crab fishers (caranguejeiros) ${ }^{12}$ stick their hands into the burrows, searching for the roots. They know that the crab usually positions itself there, on its side, and they feel their way until they find its back,

11 Gaitas are mangrove plants called salambaia. Their stalks are used for attaching nets. Once they are removed, they are called gaitas.

12 Those who call themselves 'gatherers", with knowledge of how to grab crabs (v. Araújo 2017) 
pulling it by its hind legs. When it is in its burrow the crab's movements are compromised, which makes it more difficult for it to defend itself.

There is also the "lid" technique, which involves covering the burrow with mud. After some time, the crustaceans start to come up and they can be pulled out by crab fishers:

That mud goes down there, then it blocks, steps on the burrow, and then it loses its breath and comes burrowing through the mud. When it reaches the top that's when you wrestle the crab, the arm goes to get him. But in the big tide you put the net, in the dead tide which dries up the mangrove that's when you you use the lid (Silvinha. Interviewed in December 2016).

Among the traps used is the "little net", which is forbidden by the Brazilian Environmental Agency (IBAMA), since it impacts on the crab population. The technique works in the following way: a small discardable net is placed in the burrow, and as the crab exits it is trapped. Once it has been caught, the net fragments are generally left behind, which is not only polluting, but also puts other crabs at risk, as they get tangled to them. Speaking of this technique, Silvinha affirms he is against it, mainly because it pollutes the mangroves. He says that whenever he finds net residues, he burns them, using the wood stove fathom (called "fire mouth") he keeps in his canoe. To catch the blue land crab, which is most admired, and which is most valuable commercially, he prefers the "rat trap", described in the previous section.

Using Silvinha as a privileged interlocutor, I took note of a final temporality, with a weekly cyclicity, that joins those that have already been described. These are Silvinha's weekly cycle of activities. I intend to show how he organizes and deals with time and with his activities, which are tied to various aspects of mobility and to specific competences. Below I present a table ${ }^{13}$, featuring the days of the weeks and their respective tasks. This tool depends on the analysis of empirical data, which are not employed in a rigid manner: the processes described are dynamic. The movements and flows reflect aspects of daily life and of the organization of tasks.

The peculiar manner that Silvinha organizes his time and activities, displayed schematically, is crucial for understanding not only the itineraries, but also the organization of work, itself influenced by ecology, since most activities are carried out in different environments. From this point of view, the activities described in the table are defined by a set of times which include limits, contingencies and scales, that tie them to specific technical skills. This process of diversifying activities is what enables access to equally diversified knowledge, which jointly contribute to the organization of households.

Carrying out the activities involve material and immaterial principles, in which ecological elements also figure, such as the rhythms of the tides and the seasons. The technical dimension that conducts these relations is refined through physical and chemical knowledge, that turn on skills that derive from diverse flows, constructed out of a range of experiential resources.

The activities are not carried out in a static manner, since they are related to other acts at political and commercial levels, and to exchanges that depend on alliances and physical, political and administrative constraints, the articulation of which draws a map of the conditions of access to resources. They contribute to determine the repertoire of possibilities (Mura 200o) of the household, as well as the itinerary of activities that its members will follow.

It should be taken into account that the activities articulate with each other, defining cycles. When the tide is not right for fishing, for example, Silvinha takes care of the cattle ${ }^{14}$ of his household. These animals are tethered to fenced areas of a house's yard. However, cattle are released every day and taken to pastures (see photos). Manure is also used as fertilizer for Silvinha's households gardens.

\footnotetext{
13 It should be stressed that the activities described in the table should not be interpreted statically, since they correspond to the social organization of work, involving various members of the households that I researched.

14 Cattle are a sort of provision. When the household faces a financial crisis, its members tend to sell a few heads of cattle.
} 
These activities depend on the radius of activity, of Silvinha's comings and goings to the mangroves and the pastures, of fish obtained and consumed or sold. These flows produce processes of domaining that contemplate different strategies of relating and interacting of people and elements of the environments. To reach the mangroves I need to move across spaces that are not exclusively mine, including the yards of my neighbours and acquaintances. For this to occur, one needs to be on good terms with the owners of these spaces, or else other itineraries have to be devised. The owners of the forests and the mangroves also need to be pleased ${ }^{15}$. Strategies for building and maintaining good relations, centred on moral obligations and practical experiences, allow one to precisely extend control over the spaces that are to be utilized. Yet these relations must be always renewed and ratified, particularly following accidents or misunderstandings, when ensuing tensions and conflicts may threaten access to spaces and their desired resources. An example of this occurred to Silvinha. One time, his cattle invaded the gardens of his brother-in-law's ranch, causing extensive damage, which led to a conflict within the household. As a consequence of this oversight, Silvinha was barred from accessing the spaces over which his brother-in-law held domain, consequently altering his trajectories, mobility and the rhythms of his activities, particularly in relation to livestock husbandry.

The rhythmic dimension also results in the development and use of techniques. This integration is converted in different forms, but particularly at the level of a perception of the individual in space, in her movements produced by her practices, such as in trips to the garden, to mangroves, to pastures, to other environments. According to Leroi-Gourhan:

“...perception of the surrounding world occurs in two ways, one, dynamic, consisting of travelling through space and thereby taking conscience of it, and another static, allowing, by its immobility, to reconstitute successive circles around us, which progressively blur into the limits of the unknown" (1965, p. 134).

We can thus say that the movements produced by individuals enable activities to be carried out, through individual and collective strategies, directed at configuring calendars, itineraries, rhythms, so as to create an efficacious technical medium.

In this same perspective, Mura and Barbosa da Silva (2018, p. 12) analyse the movements produced by the jeheka ("to go look for") practice of the Guarani Kaiowa:

The very mode of movement and use of space derived from the jeheka experience, through oguata (wandering) - which, as we have seen, encounters its cosmological sublimation in the time-space of origins, in the formation of tracks by the gods - occurs by strongly valuing centres of irradiation, with the Earth itself having developed from a disk, which later became the Earth's own navel. In this context, therefore, we speak of a modality of construction of territories from centres of wandering irradiation. In other words, the Kaiowa people construct spaces of use and occupation through an "irradiated itineration". In fact, jeheka activities and those arising and/or correlated with them have an axis, that is, the point of departure and arrival, in the residential spaces of the various Kaiowa households.

This explains rhythms in their many centres of irradiation and itineration, conferring amplitude to the spatial activities of the Kaiowa. This dynamic of rhythms is also conformed in the practical experiences of the Potiguara, at the level of a perception of the territory, who, through movement, gain access to it and transform it in the rhythm of their activities, in the dynamic of the tides and the seasons.

\footnotetext{
15 Comadre Florzinha is the owner of the forest and the Father of the Mangrove owns the mangrove. These beings are respected, thanked and feared. The moral dimension which conducts this relation is evident in the punishments they mete out to those who fail to observe their demands, which range from respecting game animals during hunting and fish during fishing, to providing offerings, such as cachaça, tobacco, and honey. It is thus important to maintain a relation of proximity and exchange with these beings. This requires affinity and respect to ensure good fishing, hunting and protection so that one does not lose one's way in the mangroves and the forests.
} 
It is also noteworthy that the members of a domestic unit carry out various types of activities, resulting in a complex and diversified temporal concatenation. Calendars deriving from the bureaucratic time of the Brazilian State, from agricultural and fishing activities, from the sugar mills, the tidal regimes, climatic and seasonal factors, all provide a backdrop for the Potiguara of Jaraguá village, out of which they construct temporalities that establish an alternation of activities and the mobilities that derive from them, marking contextual spatialities. These cycles orient the lives and routines of people and result from practical experiences and decision-making processes that enable the articulation of different activities, ensuring the reproduction of local groups in time and space.

Weekly calendar of Silvinha's activities

\begin{tabular}{|c|c|c|c|c|c|c|c|}
\hline & SUNDAY & MONDAY & TUESDAY & WEDNESDAY & THURSDAY & FRIDAY & SATURDAY \\
\hline 焉 & $\begin{array}{l}\text { 1:oo, "unfish", } \\
\text { bathes and } \\
\text { waits for the } \\
\text { tide to rise } \\
\text { back. Gets } \\
\text { home at 4:0o, } \\
\text { rests, and at } \\
\text { 9:oo goes to the } \\
\text { mangrove to set } \\
\text { up his net. }\end{array}$ & $\begin{array}{l}\text { 4:0 returns } \\
\text { home. Pause to } \\
\text { rest. 8:0o cleans } \\
\text { the fish along } \\
\text { with his wife, } \\
\text { son and moth- } \\
\text { er-in-law. } \\
\text { Afternoon: goes } \\
\text { to his brother } \\
\text { Zé Boto's house. }\end{array}$ & $\begin{array}{l}\text { (Dead tide). } \\
\text { 6:oo takes cattle } \\
\text { to pasture } \\
\text { 14:oo brings } \\
\text { cattle to the } \\
\text { fence in the } \\
\text { yard. }\end{array}$ & $\begin{array}{l}\text { (Dead tide) } \\
\text { 9:oo fixes faulty } \\
\text { nets. } \\
\text { Afternoon: goes } \\
\text { to the man- } \\
\text { grove to gather } \\
\text { the gaitas, } \\
\text { which attach } \\
\text { the net to the } \\
\text { mud. }\end{array}$ & $\begin{array}{l}\text { (Dead tide) } \\
\text { 8:oo cuts grass } \\
\text { for cattle. } \\
\text { 16:oo cleans } \\
\text { his garden } \\
\text { (removes un- } \\
\text { derbrush). }\end{array}$ & $\begin{array}{l}\text { (Dead tide) } \\
\text { Leaves 8:oo. } \\
\text { gathers "tame" } \\
\text { mangrove for } \\
\text { coal and rafters } \\
\text { to make a hen- } \\
\text { house. }\end{array}$ & $\begin{array}{l}\text { (Breakimg tide) } \\
\text { Leaves 13:00, ar- } \\
\text { rives 14:00, sets } \\
\text { up his net and } \\
\text { returns home. } \\
\text { Leaves 18:0o to } \\
\text { raise the net. } \\
\text { "Unfishes" } \\
\text { at 22:00, and } \\
\text { sets up the net } \\
\text { again. }\end{array}$ \\
\hline
\end{tabular}

Elaborated by the author, 2017.

Spatial range of some of the activities carried out by Silvinha in Jaraguá village

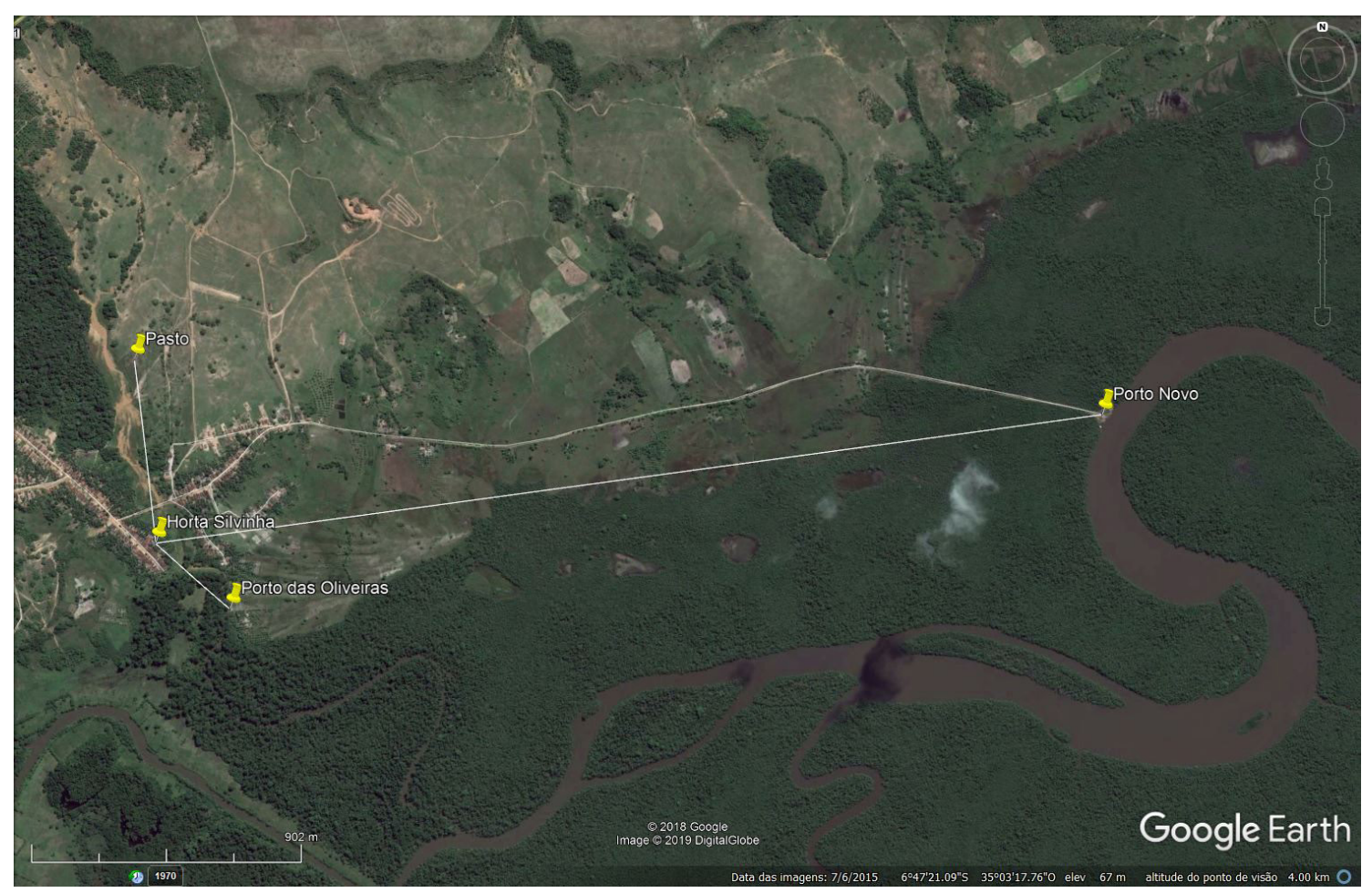

Elaborated by the author, using the Google Earth programme, 2017. 

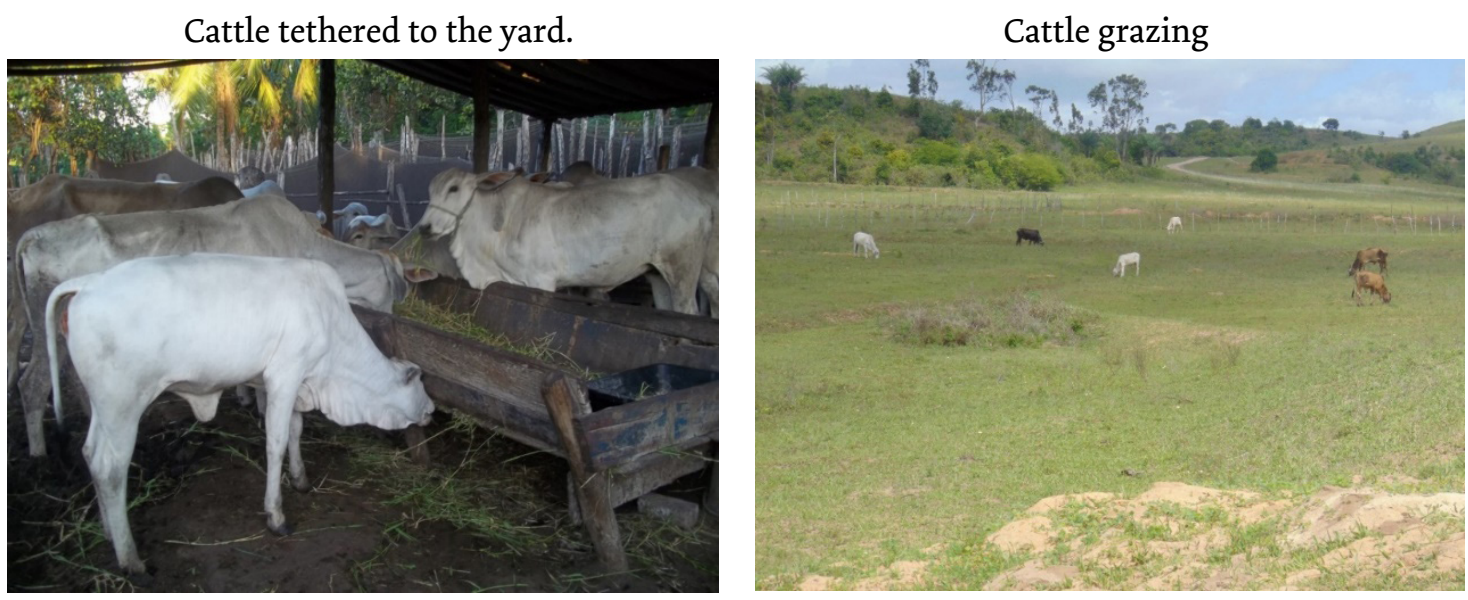

Photos by the author, 2017 .

\section{Final Thoughts}

This article has presented technical concatenations and transformations that occur in specific socio-ecologicalterritorial contexts. These contexts are constructed through relations and interactions between knowledges, materials and social and cultural factors, in specific environments, which allows Potiguara households to carry out diverse activities through individual and collective strategies. In the process, individuals elaborate a complex association of materials of different provenance, such as plastic, metal, rubber, vegetal and animal fibres, among others, which are articulated according to needs that arise within households at the local level, defining temporalities and movements of people and things. This article has thus sought to understand how technical systems are generated and transformed by multiple causes, apprehending the complexity and importance that these technical transformations manifest.

This situation results in experiences that accumulate through the refinement of skills and orientations that turn on what we call a household ecology, understood as a product of the activities that members of households carry out, exploring environments and defining control over spaces through specific processes of domaining. These processes create the conditions for the establishment of itineraries, contemplating mobilities and rhythms that are motivated in terms of local knowledge and political relations, technically necessary for regulating the accessibility and availability of material in the territory. Household ecology is thus in continuous transformation, producing complexity and heterogeneity of technical acts through long experience of life in the environments. These experiences furthermore reveal how the emergence of competences and skills is dynamic, allowing us to apprehend traditional knowledge not as the result of the simple inheritance of past knowledge, but as a specific, present, modality of accessing, organizing and concatenating diversified materials, taking into account their physical, chemical and technical properties rather than the nature of their provenance.

Received: September 19, 2018

Approved: October 07, 2019

Translated by Luiz Costa 


\section{Bibliography}

ARAÚJO, Marianna de Queiroz. 2015. "Entre terreiros, roçados e marés: Um estudo sobre a organização doméstica entre os Potiguara do Litoral Norte da Paraiba". Monografia (Graduação em Antropologia) - Centro de Ciências Aplicadas e Educação, Universidade Federal da Paraíba, Rio Tinto.

. 2017. "Ecologia doméstica e transação de conhecimento entre grupos domésticos potiguara da aldeia Jaraguá de Monte- Mór, PB”. Dissertação (Mestrado em Antropologia). João Pessoa: Universidade Federal da Paraíba, 2017.

BARBOSA DA SILVA, Alexandra. 2009. "Entre a aldeia, a fazenda e a cidade: ocupação e uso do território entre os Guarani de Mato Grosso do Sul. Tellus, 16: 81-104.

; ANDRADE, Lara Erendira A. de; ARAÚJO, Marianna de Queiroz. 2017. “Ecologia doméstica e tradição de conhecimento: formas de resistência entre os Potiguara da Paraíba e os Kapinawá de Pernambuco" In: BARBOSA DA SILVA, Alexandra et.al. (org.). Território, ambiente, identidade e poder: reflexões a partir de múltiplas perspectivas. João Pessoa: Editora da UFPB, pp. 19 - 42.

; MURA, Fabio. 2018. "Territory and domestic ecology among the Kaiowa of Mato Grosso do Sul ".

Vibrant, 15 (2): 1-22.

BARTH, Fredrik. 200o. "A análise da cultura nas sociedades complexas". In LASK, Tomke (Org.), O guru, o iniciador e outras variações antropológicas. Rio de Janeiro: Contra Capa Livraria.

CARDOSO, Thiago Mota.; GUIMARÃES, Gabriella Casimiro. (Orgs.) 2012. "Etnomapeamento dos Potiguara da Paraiba”. Brasília: FUNAI/CGMT/CGETNO/CGGAM. (Série Experiências Indígenas, n. 2).

CORDELL, John. 1974. “The Lunar-Tide Fishing Cycle in Northeastern Brazil”. Ethnology, vol. 13, n. 4, pp. 379-392 .

EVANS-PRITCHARD, E. 2005. "Os Nuer: uma descrição do modo de subsistência e das instituições políticas de um povo nilota”. 2 ed. São Paulo, Perspectiva.

INGOLD, Tim. 2012. "Trazendo as coisas de volta à vida: Emaranhados criativos num mundo de materiais". Horizontes Antropológicos, 18 (37): 25-44. . 2015. "Estar vivo: ensaios sobre movimento, conhecimento e descrição". Petropólis, RJ: Vozes. ; KURTTILA, T. 2000. "Perceiving the environment in Finnish Lapland". In: Body and Society, $6(3-4): 183-196$.

LEMONNIER, Pierre. 1993. "Technological choices: transformation in material cultures since the Neolithic". London: Routledge.

LEROI-GOURHAN, André. 1965. Le geste et la parole II: La mémoire et les rythmes. Paris: Albin Michel. . 1984. "Evolução e técnicas I: O homem e a matéria". Lisboa: Edições 70.

MURA. Fabio. 200o. "Habitações Kaiowá: Formas, propriedades técnicas e organização social”. Dissertação de Mestrado apresentada ao PPGAS do Museu Nacional-UFRJ. Rio de Janeiro.

. 2011. "De sujeitos e objetos: um ensaio crítico de Antropologia da técnica e da tecnologia". Horizontes Antropológicos, 17(3): 95-125.

OLIVEIRA, João Pacheco de. 2004. “Uma etnologia dos 'índios misturados'? Situação colonial, territorialização e fluxos culturais”. In J. P. de Oliveira (Org.). A viagem da volta: Etnicidade, Política e Reelaboração Cultural no Nordeste Indígena. 2르. Ed. Rio de Janeiro: Contra Capa, pp. 47 - 77.

PALITOT, Estevão Martins. 2005. "Os Potiguara da Baía da Traição e Mont-Mor:história, etnicidade cultura”. Dissertação (Mestrado em Sociologia) - Universidade Federal da Paraíba, João Pessoa.

VIEIRA, José Glebson. 2012. "Amigos e competidores: política faccional e feitiçaria nos Potiguara da Paraiba". Tese (Doutorado em Antropologia) - Universidade de São Paulo: USP. 
WEBER, Max. 1999. “Comunidades étnicas”. In: Economia e sociedade: fundamentos da sociologia compreensiva. (tradução de Regis Barbosa e Karen E. Barbosa; Revisão técnica de Gabriel Cohh) Brasília; Editora Universidade de Brasilia: São Paulo: Imprensa Oficial do Estado de São Paulo, pp. 267 - 277. WILK, Richard, et al. 1984. "Introduction”. In R. McC. Netting; R. R. Wilk; E. J. Arnold (editors), Households. Comparative and historical studies of the domestic group. Berkeley: University of California Press, pp. 217 - 244.

. 1977. "Household ecology": Economic change and domestic life among the Kekchi Maya in Belize. DeKalb: Northern lllinols University Press.

Marianna de Queiroz Araújo

PhD Student, Graduate Program in Anthropology, Federal University of Paraíba, João Pessoa / PB, Brazil. https://orcid.org/0000-0002-1182-449X

Author's e-mail: mariannaqueirozaraujo@gmail.com 